\title{
Substance abuse and domestic violence within families: a pastoral hermeneutical response
}

\begin{abstract}
Substance abuse among young people is an ever increasing reality and one of the most significant contributing factors to domestic violence within families. The essential question is how practical theology and, to be more exact, pastoral interpretive guides (within the local church) can contribute to assist individuals, families and communities in dealing with this traumatic reality in a responsible way. This article argues for a theologically responsible pastoral hermeneutic as it engages with the challenges of the presented case study, within a transdisciplinary approach.
\end{abstract}

\section{INTRODUCTION}

Adolescent chemical addiction is a serious and growing worldwide epidemic in almost all social environments. It is estimated that some twenty percent of adolescents who experiment with chemical substances become addicts. Some of the reasons behind adolescent chemical addiction are grounded in seeking excitement, economic reasons, negative peer pressure, family problems, a poor self-image, lack of knowledge regarding the impact of chemical substances, negative environmental factors, and a way to deal with problems (Gouws et al., 2000:182; United Nations Office on Drugs and Crime, 2002:22).

Methamphetamine or speed (tik) is particularly popular among adolescents as it provides them with self-confidence, energy and a sense of power (Caelers, 2005:1; Ganga, 2007). Addiction threatens the wellbeing of adolescents, the ability to complete relevant development tasks, the ability to become independent adults, to find meaning in life and to live a healthy lifestyle. In addition, it places a burden on caregivers such as educators, social workers, religious workers and, last but not least, parents and families.

The fundamental question practical theologians will have to ask is: What will be a responsible way to deal with substance abuse and domestic violence within families and communities? This article will try to grapple with this fundamental question by using a responsible theological pastoral hermeneutic in dealing with drug abuse and domestic violence. ${ }^{1}$ Firstly, this article will try to understand the context of substance abuse and domestic violence in our society by means of a case study, Secondly it will indicate the importance of a transdisciplinary approach in dealing with drug abuse and domestic violence and focus on understanding and interpreting the context of a specific case of drug abuse within domestic violence; and finally, it will indicate how a constructive ecclesiology could assist interpretive guides (pastors) in dealing with these complex issues in a responsible and constructive way.

1 For the tasks of practical theology and the questions related to it see Osmer (2008). Osmer (2008) explains that practical theology makes its own constructive contribution to the theological enterprise as a whole and to the ongoing conversation of humankind in its quest for intelligibility. Within this process, he explains that practical theology carries out four mutually related intellectual operations: the descriptiveempirical, interpretive, normative and pragmatic. 


\section{A CASE STUDY ON SUBSTANCE ABUSE AND DOMESTIC VIOLENCE}

The article wants to indicate the context of substance abuse and domestic violence in our society by means of a case study in order to understand the impact it has on individuals, families and the community. This true story of Ellen Pakkies designates the lack of human dignity in our society. ${ }^{2}$

The story of Ellen Pakkies unfolds as follows: She lives in Dover Court in Lavender Hill, near Cape Town. She is married to Odniel and they have three boys. She had a very difficult childhood and an abusive life, but nothing could prepare her for the abuse she would suffer at the hands of her last-born child. It resulted in her killing him. Her youngest son, called Adam or Abie as he is known to family and friends, is addicted to Crystal Methamphetamine, or tik as it is popularly known. He started using drugs when he was 14 years of age. He has been fully addicted for some time and therefore has abused his mother by stealing virtually everything that they own.

Because of his violent behaviour, she has kicked him out of the house many times. She had no other choice, because he has verbally abused her by swearing at her and he has also physically abused her for many years and even once threatened to kill her. Neighbours remember Abie Pakkies as a drug-addicted monster, who was horrible to his mother. He threatened both his parents at knife point, set fire to their curtains and stole his mother's underwear in a relentless quest to fund his Methamphetamine habit. He would come home to look for food and out of fear; she served him supper through the bars of the safety door. It was difficult for her, because she hated seeing her child standing outside all the time. She desperately wanted to see him change and to trust him again. She tried so many times to believe that he has changed but was always disappointed. The nearby Steenberg Police Station confirmed that Ellen had laid six complaints against her son in the three years before she killed him - for stealing copper pipes, CDs, clothes and shoes, and for possession of drugs.

One day when he came to look for food again, she felt sorry for him and let him into the house so that he could make himself a sandwich. She thought that if she locked her bedroom door, he would not be able to steal what was left of their valuables. But no sooner had she opened the steel gate when she discovered a bag of stolen goods in his room again.

A couple of hours later, Abie came back, banging on the door, pleading for money. He did not stop until she threw a R20 note out the kitchen window, just to stop the nagging.

Ellen couldn't sleep that night. Thoughts of her troubled son had kept her awake all night. Her youngest son had upset her and she wanted to talk to Abie that same day; she would tell him she has had enough. This tik nonsense had to stop; it was time for him to pull his life together. If the police could not talk sense into him, she would.

She heard him jump over the fence. She did not mind because he had no other way of getting to his room - a hokkie in the yard. He was no longer allowed to use the front entrance, because the risk of him entering the house is too high and she wasn't going to make the same mistake again - he's taken too many of their things to sell for tik or buttons.

When she got to Abie's room, she found him in another drug stupor. He was lying face-down on the floor, next to his bed. The $3 \mathrm{~m}$ by $2 \mathrm{~m}$ room had almost nothing left in it. Most of his drawings, music tapes and even his clothes have been sold or discarded. All that

2 Although there are many themes and issues that could be taken from this case study, this paper would want to focus on the themes of drug abuse especially methamphetamine (tik), domestic violence, and the challenge to human dignity. 
remained was a bed, a table, four steel walls and an unbearable smell - Abie hasn't washed properly for days. He must have been cold after a long night away from home. Ellen asked him if he wanted tea. "Hmm", he murmured vaguely. He didn't open his eyes.

Ellen went back to the kitchen and made his tea - heaping three sugars and pouring milk into the mug, just the way he liked it. She returned to the hokkie and looked down at her sleeping son. She put the tea down and left to say goodbye to her husband. She waved goodbye to him from behind the steel gates of their front door.

Then she walked to Abie's old bedroom - the one that he lived in before tik took over his life. The walls were once plastered with inspirational posters. The space was once filled by his double bunk bed, his soccer balls and cricket bats, and tapes of him and his friends rapping. It had been once full of life, but now, as Ellen entered the room, there was only a TV, couches, a broken computer and a rope on a desk. A rope no thicker than an adult's finger, but strong enough to tow a bakkie. She picked up the rope. She didn't know what she was thinking - her mind was a blank. She just stood there, with the rope in her hand. She felt calm.

Ellen than returned to Abie's hokkie. He's picked himself off from the floor and was now sleeping on his bed. The tea remained untouched. For the second time that morning, she stood over her boy. She was flooded with thoughts - thoughts of the sweet baby he had once been and the monster he had become. The rope was still in her hands. She tied it into a noose. She slipped it over his neck. Abie woke up. He blinked back his confusion.

"Mommy, what now?" He felt the noose around his neck. Suddenly Abie realized what was happening. He fought back. He grabbed a plank off the floor. He lunged at his mother with the wooden board, but he couldn't reach her. Ellen kept her composure. The rope wasn't tight - she only wanted to talk. But Abie looked scared, and swore at her. $\mathrm{He}$ called her a xxx like he had so many times before. She hated it when he swore.

Ellen told her son to put the plank down. He refused. "Abie, why don't you appreciate what I do for you? I will go out of my way to do for you whatever I can." Abie ignored her. He just lay there, his eyes wide open. "Abie, now why don't you listen?" "Mommy, I'm going to," he replied in a feeble voice, but Ellen had heard this too often. "No, I've had enough of that," she said. Then she pulled the rope tight. Her grip was so firm it cut through her skin. Blood trickled from her hands. She wiped off some of the blood with an old T-shirt of Abie's. But she continued to pull. She pulled tighter and tighter. She wasn't angry. She didn't feel anything; she was just calm. It was quick. Abie's body jumped into the air. His hands reached out for support, for anything, for his mother. She kept on pulling the rope. Ten seconds, twenty, thirty seconds. At last Abie's body was still, lifeless. At first she thought he was just acting; he'd always been a good actor, but this time her son didn't stir; and didn't get up. Ellen left the hokkie and went into her house where she washed and put on her uniform for her job as caregiver of the elderly - navy-blue pants, a matching scarf and a white blouse. It was only then that she began to realize what she's done.

Ellen stepped into the morning chill and hurried to the train station. The morning had broken, the sun was up, Dover Court was buzzing with schoolchildren and housewives, their voices ringing through the square. Ellen looked at the people who scurried past her, some aimlessly, others with places to go. She took a deep breath. She would force herself to go to work. The cleaning lady would make her coffee, assuring her that everything was okay. Ellen would shake her head. "No, nothing's okay," she will tell her. "I just killed my son."

She was sentenced to three years imprisonment, suspended for three years. Her sentence included three years of correctional supervision and 380 hours of community service. (Leila Samodien, http://capeargus.co.za/mapinc.org/media/2939) ${ }^{3}$

3 This case study was compiled from various articles from newspapers. 


\section{TRANSDISCIPLINARY APPROACH}

The above case study evokes many questions as it sinks into the soul of our humanness. The intensity of this case study emphasises the responsibility of practical theologians to deal with substance abuse and domestic violence within families and communities in a responsible way. In the past, practical theologians focused to a large extent on the church environment and were guilty of attempting to deal with these and other complex and challenging issues on its own. It is therefore understandable why Cilliers (2006:625) states that practical theology has to a large extent traditionally operated within a clerical and ecclesiological paradigm. As the complexity of the South African society increases it became clear that practical theology within a clerical and ecclesiological paradigm is too limited to deal with these complex life issues.

This article therefore wants to argue for a transdisciplinary approach to deal with complex life issues. Before arguing for a transcultural approach it is relevant to take note of Osmer's (2008:163) emphasises on cross-disciplinary dialogue. He defines it as follows: 'cross-disciplinary dialogue is a special form of rational communication in which the perspectives of two or more fields are brought into conversation. It can take on different forms.'

The key part of this definition is the focus on the 'rational communication in which the perspectives of two or more fields are brought into conversation with one another'. This is indeed a plea for real, constructive cross-disciplinary dialogue. My assumption is that this does not come natural for practical theologians; on the contrary, it is something we need to learn to do. This is rather puzzling, because it is supposed to be a fundamental part of our identity and therefore ought to be a natural component of practical theologians.

In a contribution by Jürgen Mittelstraß, 'Methodische Transdisziplinarität', in Technikfolgenabschätzung, he argues for a transdisciplinary approach. The term transdisciplinarity is used instead of interdisciplinary or crossdisciplinary, because 'inter-disciplinary' designs a concrete cooperation of several disciplines working on a particular topic, whereas transdisciplinary goes further to imply a continuous cooperation of different disciplines. Those disciplines involved in the research also accept that change can take place in the orientation of their scholars as well as in the boundaries of disciplines in the process of cooperation.

Transdisciplinary dialogue is something practical theologians will need to toil actively towards. Maturity as an academic (person), a well-based and well-formulated theology, knowledge of the field of practical theology, a willingness to learn from and engage with other academic fields, and be open for change in your own approach and academic field are some of the characteristics needed for transdisciplinary dialogue. These characteristics are true to what Osmer (2008:19) calls an interpretive guide. Although Osmer (2008:163) uses the term within his understanding of cross-disciplinary dialogue, I am of the opinion that it is more relevant within a transdisciplinary context. Osmer (2008:19) argues that the congregational leader needs to be a pastoral interpretive guide that can practice and integrate these attributes in order to take the congregants on a journey into new territory. The congregational leader travels along with congregants on their journey towards healing and wholeness.

To guide people through this complex situation the pastoral interpretive guide will need to take ownership of practical theology and comprehend that it is indeed a form of theology. It is not a second- class science. It uses the concepts, methods and sources of theological discourse to develop a constructive theological perspective. Secondly it brings this perspective into dialogue with other fields, including other theological disciplines, as well as the arts and sciences (Osmer, 2008:163). After reflecting on this, I realised that there could be many reasons for this, but the main reason could be that practical theologians are not clear in terms of their identity and how to address the complex issues as indicated in the case study. 
Practical theologians need to remember that practical theological interpretation should be deeply contextual and therefore it needs to think in terms of interconnections, relationships and systems (Osmer, 2008:17). With this in mind, it is imperative that practical theologians will need to engage in dialogue with the social sciences and be able to discern the research methods and approaches that are best suited for researching the issues in this case study. In its interpretive work, practical theologians will engage with the social sciences, natural sciences, political and economical sciences and philosophy to place particular episodes, situations and contexts in a broader explanatory framework. In constructing a normative perspective, they will enter into a dialogue with dogmatic theology, theological and philosophical ethics, anthropology and normative social theory. In its pragmatic task, they will engage the action sciences like education, therapy, organisation change theory and communication theory. It is inevitable for practical theology to engage at every point in transdisciplinary thinking, but at no point does it merely take over the methods and frameworks of cognate fields. It engages them critically as part of a trans/cross-disciplinary conversation in which the distinctive theological perspective of practical theology retains its own voice (Osmer, 2008:17).

In terms of the case study, a transdisciplinary approach would lead to the creation of a transdisciplinary professional team which would consist mainly of a social worker, medical practitioner, psychologist, youth worker and a pastoral interpretive guide. The requirements for these role players within the team would be to: be concerned about the addict because they care; have expert knowledge of the phenomenon of drug addiction; have enough objective knowledge, be able to exert and be able to work holistically. It is essential that the role or function of the transdisciplinary professional team be to create a space for healing, to move at the pace of the client, to support, motivate, confront or refer as the need arises, and to assist people to find meaning in their situation.

What can pastoral interpretive guides discover from other disciplines in terms of the case study? ${ }^{4}$ From the social sciences interpretive guides can discover that Methamphetamine or speed (tik) has a long history and is not something new, ${ }^{5}$ and can learn about the characteristics of this drug. ${ }^{6}$ The social sciences further link drug abuse to high risk behaviour. High risk behaviour is when a person acts without consideration or awareness of the possible consequences of their actions. It is understandable that young people will experiment with drugs, because they have a desire to be accepted and they are curious. Young people are mostly not aware of the consequences of taking such risks, which could lead to: suicide ideation and attempts; family violence and murders; child abuse and neglect; overdoses and associated effects; prostitution; unsafe sex; raping or being raped; theft, loss of short-term memory; loss of long-term memory, drunken driving; and financial losses.

4 As this article engages with the case study it needs to be emphasised that this engagement is by no means a detailed analysis of the case study, nor is it a comprehensive psychological or sociological explanation of it. The article merely want to indicate the value of some of the unique contributions from other disciplines in assisting us to understand and interpret in order to be responsibly in assisting the individual, the family and the community in the process of finding meaning within their traumatic contexts.

5 Crystal methamphetamine or speed (tik) is nothing new. Already in 1887 it was designed for medical testing and use. In 1932 it was used as a medical cure for asthma and nasal congestion. There is also evidence that Hitler used this drug on his soldiers to enhance their energy and endurance levels. It appeared as a recreational drug in Hawaii in the form of 'crystal methamphetamine' in the 1980's. In 1987 methamphetamine in its powder form was developed and sold on the streets.

6 It is characterised by a mostly white substance. It is mostly in the form of crystals or powder. It can be inhaled, swallowed, snorted or injected. It is a psychoactive stimulant that produces an odourless smoke and is bitter-tasting. The effects last for up to 24 hours. It is relatively cheap and relatively easy to manufacture and easy to obtain. 
What would then be the signs, symptoms and stages typical of methamphetamine or speed (tik) abuse? According to a methamphetamine expert, Mariechen van der Westhuizen (2010:21) the pastoral interpretive guide should be aware when there are signs of changes in personality, loss of interest in favourite things and a decline in performance and attendance. ${ }^{7}$ In terms of the symptoms of the substance abuse van der Westhuizen (2010: 22) indicates that environmental, interpersonal and social factors can contribute to substance abuse $\mathrm{e}^{8}$ and that pastoral interpretive guides should particularly understand the stages of the methamphetamine experience. ${ }^{9}$

Although the pastoral interpretative guide will need to be well aware of the signs, symptoms and stages, it is more significant that they understand and focus on the effects of methamphetamine addiction in more detail. It is helpful to describe the effects of the addiction on a cognitive, medical/physical, psychiatric and long-term level. Firstly, the effects on a cognitive level will cause chemical structure and functioning of the brain to change. It will not be metabolised in the body. These results are prolonged stimulative effects. Decreased attention abilities will occur. Learning abilities will become restricted. Damage to long-, medium- and short-term memory will become evident and the individual's motoric ability and speed will become restricted.

Secondly, the effects on a medical/physical level will have an impact on the central nervous system, cause decrease in muscle weight, convulsions, and heart problems, strokes, narrowing of blood vessels, Parkinson's disease and serious weight loss/malnutrition. Kidney failure is one of the serious effects and will be linked to liver damage, lung diseases, long-term sexual dysfunction, diarrhoea, skin rashes and jaw clenching.

Thirdly, some of the effects on a psychiatric level are conditions such as delirium - confusion; manic - extreme "high"; psychotic - hallucinations, depression, aggression, mood swings; paranoia - persecution mania, schizophrenia and depression.

Melinda Smith and Jeanne Segal (2010:1) emphasise that emotional abuse is often minimised in terms of the focus on psychological or physical harm and injury, yet it can leave deep and lasting scars. Emotionally abusive relationships can destroy a person's self-worth, lead to anxiety and depression, and make you feel helpless and alone. They further explain that emotional abuse includes verbal abuse such as yelling, name-calling, blaming, and shaming and that isolation, intimidation, and controlling behaviour also fall under emotional abuse. Additionally, abusers who use emotional or psychological abuse, often throw in threats of physical violence or other repercussions if a person fails to adhere to their needSocial sciences can help pastoral interpretive guides to be aware that substance abuse is closely intertwined with domestic violence. Fisher and Harrison (2009:2) confirm that research has indicated that the relationship between alcohol and other drugs, crime and violence has also been clearly established and that there is a clear link between domestic violence and substance abuse-related offences. Drug addiction is closely intertwined with domestic violence which has a devastating effect on the victims, the abusers, families and the community at large. It is therefore essential to define violence, in relation to domestic violence, in order to understand the extent thereof and the correlation it has with drug dependency. Steven and Lockhat (2003:136-7) choose for a contextual definition of violence by Bulhan (1985) who states that violence is any relation, process, or condition by which an individual or group violates the physical, social and/or psychological integrity of another person or group. On these grounds they state that any situation of oppression could therefore be underwritten by violence. Based on the above definition, one can safely say that violence could be closely related to poverty, oppression, racism, domestic life and xenophobia. In addition to the above, the WHO task force classifies domestic violence under, what they would call interpersonal violence,

\footnotetext{
7 For more detail on these signs and symptoms see Van der Westhuizen (2010:21)

8 For more detail on these factors see Van der Westhuizen (2010:21)

9 For more detail on the stages see Van der Westhuizen (2010: 22)
} 
because it encompasses violent behaviours which occur between individuals that is not formally planned (Stevens, Seedat \& van Niekerk, 2003:356) ${ }^{10}$.

Domestic violence and abuse does not discriminate. It happens among heterosexual couples and in same-sex partnerships. It occurs within all age ranges, ethnic backgrounds, and economic levels. And while women are more commonly victimised, men are also abused - especially verbally and emotionally. The bottom line is that abusive behaviour is never acceptable, whether it's coming from a man, a woman, a teenager, or an older adult. You deserve to feel valued, respected, and safe (Smith \& Segal, 2010:1).

Co-dependency is one of the key themes that should be pointed out in this case study. According to Beattie (1992) a co-dependent person is someone who allows the behaviour of another person to influence them in such an intense way and then want to control the behaviour in an obsessive way. Co-dependency can be described as an unhealthy and unsatisfied psychological power game between two persons in a relationship where they try to control, manage, manipulate and influence each other to behave in a way they want you to behave (Maartens, 2007:37). This is evident in the fact that the mother was and is a victim of abuse, and so is her son and both was trying to control, manage, manipulate and influence each other to behave in a way they wanted the other to behave.

This dynamic indicates that it is not only the individual that is addicted but the whole family. Family addiction is common where a member or members of the family is addicted to substance abuse. Van der Westhuizen (2010: 115) indicates that pastoral caregivers should understand that there are three phases of family addiction, namely the early, middle and final phase. These phases indicate, for example, how families initially deny the problem, then consider that there might be a problem, and then accept the problem ${ }^{11}$. In terms of the case study it is safe to say that the family was already at the end of the middle phase, where the mother was focused to confront the problem of the abuse in a direct and concrete way. She had to intervene and she did.

Concerning the discussion thus far, the clinical psychologist Martin Yodaiken, who compiled a psychological report for the Wynberg Regional Court on Ellen, indicates in his report that there was no emotion on her face; there were no tears; she told the facts, every detail, without batting an eye. In his report, he calls this a state of 'disassociation' (http://www.mapinc.org/ media/2939). She thus 'disassociates' herself from the death of her son. She holds herself at a distance emotionally, he explains, even though she is perfectly capable of expressing emotion. 'It is (my opinion) that this is a defensive reaction against the enormity of her actions in killing her son. This opinion is based on the absence of the typical emotional reaction that Mrs. Pakkies

10 These authors employ the definition of violence from the WHO task force (WHO 1996) that

distinguishes between three types of violence in the following way: Interpersonal violence encompasses violent behaviours that occurs between individuals, but are not planned by any social or political groups in which they participate. It occurs in many forms, and can be grouped into three categories according to the victim-perpetrator relationship: family and intimate violence, violence amongst acquaintances, and stranger violence. Violence between acquaintances and strangers also includes: workplace violence (including healthcare institutions and prisons); violence in schools (including bullying); communitybased violence (that does not further the aims of a formally defined group or cause); youth violence (that does not further the aims of a formally defined group or cause); sexual violence between strangers or acquaintances; and crime related violence. Self-directed violence involves intentional harmful behaviours directed at oneself. Organised violence is violent behaviour planned to achieve the specific objectives of a social or political group. It includes political violence involving carefully executed efforts to intimidate an opposing political faction violently. Genital mutilation of women and men in the name of religious and cultural rites of passage might also be considered a form of organised violence. As a last example, war is the most highly organised form of violence.

11 See van der Westhuizen (2010:115)for a more detailed explanation of the content. 
has to events which are traumatic to her.' That's why he said that Ellen was in this state of disassociation when she murdered Abie (http://www.mapinc.org/media/2939).

When referring to Abie, Yodaiken told the court that Ellen had two distinct sides to her personality - the 'loving mother' and the 'abused woman'. While the loving mother had protected and cared for Abie throughout his tik addiction, the 'abused woman' had acted out in killing him (http://www.mapinc.org/media/2939). An example of the workings of these two sides was the day of Abie's funeral, he said. Even though the 'abused woman' had murdered her son, the 'loving mother' was able to stand up in church just days later and pay tribute to him at his funeral after the planned speaker failed to turn up. This loving mother from Lavender Hill also asked a group that gathered to mark the start of the sixteen Days Campaign of Activism for No Violence against Women and Children, for forgiveness for murdering her tik-addicted son more than a year ago. She turned herself in. She was even prepared to go to jail for life.

On the other side, Yodaiken said Ellen had endured years of abuse at the hands of Abie physical and emotional (http://www.mapinc.org/media/2939). His report documents a life of abuse. As a child, Ellen was abused by her parents, she was abused by men she became involved with and then she was abused by her own son. The stress of this lifetime of abuse had slowly mounted until she reached breaking point (http://www.mapinc.org/media/2939). 'There is an accumulation of emotions that eventually exploded,' Yodaiken testified, adding that the murder was spontaneous. All the past perpetrators had suddenly taken the image of her present one: Abie (http://www.mapinc.org/media/2939).

The contributions from other disciplines enable pastoral interpretive guides to understand the complex context of Ellen in a holistic way, and this empowers the pastoral caregiver to participate and contribute in a responsible way.

\section{JOURNEYING TOGETHER FOR MEANING AND SIGNIFICANCE}

The further question this contribution wants to grapple with is: What is the unique approach and contribution of practical theology within a transdisciplinary dialogue?

Practical theology is in essence hermeneutical, because it has to do with understanding and interpretation. A hermeneutical process is a deeply transformative process. For practical theology to be able to interpret in order to contribute to the process of transforming our society it must be deeply contextual. Hermeneutics is therefore not a quick way to solve the problems of our society in order to transform it. It is rather a process to listen and to explore in order to understand and interpret as we journey together with others into new territory. In terms of this, Osmer (2008:17) states that therefore it needs to think in terms of interconnections, relationships and systems.

Furthermore, it is a process that involves the interpretation of the meaning of the interaction between God and humanity, the edification of the church, and becoming engaged in praxis through communities of faith in order to transform the world or to impact on the meaning of life (Louw, 1998: 97). Therefore, practical theology tries to interpret and translate the praxis of God in terms of human and existential issues through the action of communities of faith. It is a process of guiding the congregation as a community of understanding and interpretation to be able to facilitate families on their journey towards healing and transforming. The local congregation should therefore be able to create a safe space for families to deal with substance abuse and domestic violence in a constructive way.

The goal of pastoral care is to understand the encounter between God and humans from the perspective of the confronting effect of God's grace, presence and identification with human need and suffering. It interprets this confrontation in such a way that God's care reveals a 
horizon of meaning, which in turn gives hope and generates faith (Louw 1998:99). Pastoral care is therefore essentially about listening and seeking to understand and interpret in order to find meaning within the hope of the resurrected Christ, the indwelling of his Spirit and the coming of Christ (eschatology).

Pastoral hermeneutics is not only about God's relationship with us and our relations with each other; it is also about restoring the relationship with us and with each other. The hermeneutical challenge is how to move from the Biblical text to a current understanding of human identity within the context of the victim and abuser. Within the hermeneutical paradigm, the victim and abuser both need to be understood within their context as fully human beings, as relational human beings who are seeking healing and wholeness. They are affected and in need of healing, so that the relationships can be restored ${ }^{12}$ and they can, in a meaningful way, continue on their life journey. Pastoral interpretive guides thus need to not only restore the dignity of the individual but also the dignity of the family and the community.

Pastoral care within a hermeneutical paradigm is also deeply about a theology of life and the healing of life. It is about the dwelling in the presence of the pathos of the suffering Christ. It is about the question how the perspective of the resurrection in Christ, and the indwelling presence of his Spirit, can contribute to the empowerment of human beings. It is about hope, care and the endeavour how to give meaning to life within the reality of suffering, our human vulnerability, and the ever existing predicament of trauma, illness and sickness (Louw 2008:11). Therefore, the objective of practical theology is to journey with Ellen and her family, but also the community, towards identity, growth, transformation, development in faith and ultimately finding meaning within there own situation. Cilliers (2006:625) rightfully says that practical theology hinges on a hermeneutics of significance, which should not be seen as a new form of clerical or ecclesiological power of control, but rather as a collaborative and reciprocal way of serving and enriching life as it is expressed and experienced in society. The indwelling presence of God's Spirit enables pastoral interpretive guides to make this possible.

Practical theology should therefore develop an ecclesiology to remind the local churches of their vocation and to know how to participate and what their role is when they encounter real life situations as indicated in this case study. An integral part of the vocation of the church is to assist victims and abusers in a dignified way. Therefore the church needs to be reminded that human dignity is conferred by God and God alone. Soulen and Woodhead (2006:6) state that Christians need to remember that human dignity is not a self-grounded possession enjoyed apart from the relationship to the Creator, Redeemer, and Sanctifier. Dignity consists of reaching out in love and care to others (Soulen \& Woodhead 2006:6). It is not something we keep for ourselves or for those who we want to share it with. It is something we own to give away to others irrespective of their class, age, sex or dignity. The role of the church would therefore be to restore the human dignity of all people involved - victim as well as abuser.

In this regard, Soulen and Woodhead (2006:6) argue that human dignity's indispensable context is the church, the gathering of the faithful. Claassens (2010:9) quotes an essay, 'Recovering Human Dignity,' by Christoph Schwöbel, who writes that the church ought to serve as 'the medium and instrument of God's creative and re-creative action in constituting and reconstituting identity and dignity.' He writes:

'... the church of Christ is committed to sharing the situation of those who have lost their dignity in human eyes and to communicating to them the message that their dignity is re-created by the one who first bestowed it upon them. In communicating this promise in speech and action, the church is called to become the witness of the recovery of human dignity because humans are dignified by God.'

12 See Claassens (2010:9) as she emphasises the importance of restoration. 
In this sense, I fully agree with Soulen and Woodhead (2006:17) when they state that the life of the Christian church is the enactment of the relationships in which the human being as relational being is constituted and reconstituted. The church is the space, a community, where everyone should have the experience that their dignity is being enabled. Poling (2010:205) describes the church as a community where all people will experience inclusive love. One could honestly argue that Ellen and her family were and are in dire need of a community where they can experience such caring and acceptance.

Although there is some truth in the argument thus far, there are also some clear red lights that demand our most urgent attention. Questions that indicate these red lights are: Has the church succeeded in restoring the dignity of people? Is it not true that the track record of the church is suspicious? Are we not, in this regard, expecting too much of the church in using strong words like: "Human dignity's indispensable context is the church, the gathering of the faithful" but with out making it happen? Will the clerical and ecclesiological paradigm not dominate and thereby limit the church in its task as it had done in many ways in the past? Does the church have a theology that assists it to enter into transdisciplinary dialogue in order to change the world we are living in?

It is impossible to even try to answer these questions in this paper. I raised these questions to indicate the complexity of entering into transdisciplinary dialogue as well as to indicate that this does not come naturally for pastoral interpretive guides.

\section{CONCLUSION}

In this contribution I have argued that the story of Ellen Pakkies is a real life reflection of a society trapped within the cycle of abuse and violence. These real life stories are very complex, extremely difficult to deal with, and the road to recovery is always a challenge, given the legacy of the past in our country and the devastating effects of this harmful cycle. As the complexity of the story of Ellen Pakkies deepens it becomes clear that practical theology within a clerical and ecclesiological paradigm is too limited to deal with these complex life issues. I therefore argued for a transdisciplinary approach as the responsible way to assist people like her, her family and the community on the journey toward healing.

I indicated how various other disciplines can assist and enrich practical theologians and pastoral interpretive guides to be able to understand and interpret the context of Ellen, her family and the community. I further pointed out that practical theologians and pastoral interpretive guides have a vocation to participate in transdisciplinary dialogue. I have argued for a hermeneutical process, because it has to do with understanding and interpreting the context. In a very real sense, it is about a process of understanding and interpreting, listening to others, the ability to be vulnerable in journeying with Ellen, her family and the community in order to discover meaning and significance. Finally it is about the contribution of pastoral interpretive guides in transforming individuals, families and communities.

\section{BIBLIOGRAPHY}

Beattie, M 1992: Co-dependent no more. How to stop controlling others and start caring for yourself. New York: Harper Collins publishers

Caelers, D 2005: Tik addiction soars at an alarming rate. Cape Argus, 7 April 2005:9.

Cilliers, JH 2009. Fides quaerens societatem: Praktiese Teologie op soek na sosiale vergestalting. Tydskrif vir Geesteswetenskappe. 49 (4): 624-638

Claassens, I J 2010: Human Dignity in the Prophetic Traditions: Upholding Human Worth in a Context of Dehumanization. Unpublished paper at a conference on human dignity at the Stellenbosch University. 
Fisher, G.L. and Harrison, T.C. 2009. Substance abuse. 3rd Edition. Boston: Pearson Education Ltd.

Ganga, C 2007. The Tik off campaign launched today. http://bushradionews.blogspot.com/2007_07_01_ archive.html (access gained 15 August 2007).

Gossop, M. 1998. Living with drugs. 4th Edition. Vermont: Ashgate Publishers.

Gouws, E; Kruger, N. \& Burger, S 2000. The adolescent. 2nd Edition. Sandown: Heineman Publishers.

Johnson, B. and Lazarus, S. 2008. The role of schools in building the resilience of youth faced with adversity. Journal of Psychology in Africa. 18(1):19-30.

Maartens, M 2007: Christelike Nood- en Traumaberading, Studiegids 2, Oowinnaars met littekens. Wellington: Bybel Media.

Mittelstraß, J 2005: Methodische Transdisziplinarität. In Technikfolgenabschätzung. Theorie und Praxis. 14/2, pp 18-23.

Osmer, R R 2008: Practical theology. An introduction. Grand Rapids: EerdmansLeila Samodien,

Poling, J N 2009: Toward a Constructive Practical Theology: A Process- Relational perspective. In IJPT vol. 13,pp. 199-216.

Samodien, L 2008: Ellen Pakkies relives strangling her addict son. http://capeargus.co.za/mapinc.org/ media/2939 (access gained 24 November 2011).

Stevens, G, Seedat, M \& van Niekerk, A 2003: Understanding and preventing violence. In, Social Psychology, Identities and Relationships by Ratele, K \& Duncan, Norman (eds) 353 - 371. Cape Town: UCT Press

Soulen, R K \& Woodhead L, 2006: God and human dignity. Colorado: Eerdmans

Smith, \& Segal, J 2010: Domestic violence in families. collegewriting2domesticviolence.blogspot.com. Thursday the 23rd of November 2011.

Steven, G \& Lockhat Rafiq, 2003: Black adolescent identity during and after apartheid. In Social psychology, Identities and Relationships by Ratele, K \& Duncan, Norman (eds) 130-147. Cape Town: UCT Press

Stevens, G, Seedat, Mohamed \& van Niekerk, Ashley 2003: Understanding and preventing violence. In Social Psychology, Identities and Relationships by Ratele, K \& Duncan, Norman (eds) 353- 371. Cape Town: UCT Press

South Africa. Department of Health/Medical Research. Umthente Uhlaba Usamite - the first South African national youth risk behaviour survey. 2003. Pretoria: Government Printer.

South Africa. Western Cape Department of Social Services and Poverty Alleviation. 2006. Transformation plan 2006. Pretoria: Government Printer.

South African Community Epidemiology Network on Drug Use. 2007. News update. Medical Research Council.

United Nations Office on Drugs and Crime. 2002. Ke-Moya-I'm fine without drugs. Pretoria: Miles and Associates International.

Van Niekerk, E. and Prins, A. 2001. Counselling in South Africa: a youth perspective. Sandown: Heinemann Publishers.

World Health Organisation. 2004. Neuroscience of psychoactive substance use and dependence: summary. Geneva.

Van der Westhuizen, M.A. 2009: Chemical substance abuse: High risk behaviour associated with HIV and AIDS. An unpublished part of a short course: Pastoral counselling and community care: Trauma, substance abuse and HIV and AIDS. At the Stellenbosch University.

Van der Westhuizen, M.A. 2010: Aftercare to chemically addicted adolescents: practice guidelines from a social work perspective. Unpublished DPhil dissertation, University of South Africa, Pretoria

\section{KEY WORDS}

Substance abuse

Families

Domestic violence

Transdisciplinary 
http://ngtt.journals.ac.za

\section{TREFWOORDE}

Middel-afhanklikheid

families

huishoudelike geweld

transdisiplinariteit

Contact details:

Dr Christo Thesnaar

Senior Lecturer in the Discipline Group of Practical Theology and Missionology

Stellenbosch University

cht@sun.ac.za 